3. My`kulina, A.K. 2016. Xudozhnya kul`tura yak naukove ponyattya ta profesijna yakist pedagoga [Artistic culture as a scientific concept and professional quality of teacher]. Pedagogical sciences: collection of scientific works. LXIX. Vol. 2. Xerson. «Gel`vetika», P. 100-104.

4. Rudny`cz`ka, O. P. 1998. Osnovy` vy`kladannya my`stecz`ky`x dy`scy`plin [Basics of teaching art disciplines]. Ky`yiv, $183 \mathrm{p}$.

5. Pidkurganna, G. O. 1998. Xudozhn`o-pedagogichna pidgotovka faxivciv doshkil`nogo vy`xovannya $\mathrm{v}$ pedagogichnomu universy`teti [Artistic and pedagogical training of specialists of preschool education at a pedagogical university]. Sankt-Peterburg. NDIX Spb DU, $277 \mathrm{p}$.

УДК [94+37.09]-042.3:37.013(485)

DOI:10.31339/2617-0833-2020-1(28)-115-117

\title{
HISTORICAL AND PEDAGOGICAL ASPECTS OF THE ESTABLISHMENT OF THE SWEDISH EDUCATION SYSTEM
}

Mochan Tatiana, Martyn Oksana

\section{ІСТОРИКО-ПЕДАГОГІЧНІ АСПЕКТИ СТАНОВЛЕННЯ ШВЕДСЬКОЇ СИСТЕМИ ОСВІТИ}

Мочан Т. М., Мартин О. М.

The article deals with the peculiarities of the development of teacher education in Sweden, which were largely related to the socio-economic transformations in the country and significantly affected the formation of the educational environment of the country. The study found that, apart from the state, a significant role in the process of reforming the Swiss education system belongs to the various religious movements that were involved in organizing the education of the country's population. At the same time, the Swiss government is laying the legal foundations of a new school that influence the formation of the national school education system and teacher training.

Key words: education system, Sweden, teacher training, reform of the Swiss education system.

В статті розглядаються особливості становлення педагогічної освіти у Швеції, які значною мірою були пов'язані з сочіально-економічними перетвореннями в державі та суттєво позначилися на формуванні освітнього середовища краӥни.

Наукові розвідки дають змогу констатувати, щзо значна роль у процесі реформування швейцарської систем освіти, окрім держави, належить різним релігійним течіям, які займалися організацією освіти населення краӥни. Разом з тим урядом Швейцарії закладаються законодавчі основи нової школи які впливають на становлення національної системи шкільної освіти та підготовку вчителів.

На основі проведеного дослідження можна зазначити, щзо в процесі становлення педагогічної освіти в Швеції спостерігаються такі основні тенденції: орієнтація на потреби школи та суспільства; удосконалення системи організації педагогічної освіти шляхом розробки та запровадження нових варіантів підготовки вчителя; зростання престижу вчительської професії.

Ключові слова: система освіти, Швеція, підготовка вчителів, реформування швейцарської системи освіти.

The development of teacher education in Sweden is linked to socio-economic transformations in the country, which have significantly influenced the formation of the educational 
field of the country. In retrospect, consideration of the problem of the historical and pedagogical conditions of teacher training is advisable to address the development of the educational system of Sweden in general (B. Bruning, E. Martens, S.-A. Selander) [1].

The study of the process of transformation of the Swedish education system as a factor that led to the formation and formulation of trends in the development of teacher training, makes it possible to argue that Swedish general education was started in the late Middle Ages (XIII-XIV centuries), when the country began to develop rapidly and all reach industries. The first schools in Sweden began to appear in the fourteenth century. They were founded by monasteries of the Franciscan and Dominican orders. At the same time, there are urban schools where elementary literacy was taught [2].

An important step was the adoption in 1527 by the Swedish Riksdag of Lutheranism as Sweden's state religion. It is known that the tenets of European Protestantism envisaged the independent development of the Scriptures by believers, which was impossible without at least primary education, the ability to read and write, to participate directly or in correspondence with the representatives of the opposing camp [3].

In the first third of the sixteenth century, the first gymnasiums were established with the initiative and support of King Gustav Adolf, a highly educated monarch with advanced educational views. Particular attention was paid to the professional level of the teaching staff of these educational institutions by the king [2].

In 1649, a prominent Czech educator, humanist, philosopher, citizen of the world, author of productive pedagogical systems, religious and public figure, Jan Amos Komensky (1592-1670) was invited to Sweden. The purpose of his visit was to assist the country's educators in reforming school education, including language, in drafting the first special legislation for Swedish high schools [4].

The year 1686 is considered the beginning of public education (involving all sections of the population in general education) in Sweden. It was this year that a church law was passed requiring the ministry of each church to provide parish children with an initial religious education and the pastors to oversee the teaching process and to check the awareness of the children in the catechism [3].

In the nineteenth century, the legal foundations of a new school were laid. The formation of the national school education system is underway, the participation of the state in its development is expanding, and the positions of state bodies in the management of educational institutions are being strengthened. This was vital because the clergy could provide elementary education only to the Lutheran population, while Sweden remained a multinational state [2].

In the mid-nineteenth century, after a long debate in the Swedish Seimas (at that time, Parliament), a law on compulsory primary education was adopted and published in the press. It should be noted that Sweden became the first among the countries in Europe, including the leading countries of that time - England and France, which adopted such an important document. Therefore, during the second half of the nineteenth century, a number of recommendations and additions to the law were developed, many of which were adopted thanks to the active work of advanced educational figures. This led to the beginning of the period of the most significant successes of the Swedish public school (late 60's - early 70's of the XIX century) [3].

The social and educational movement that took place in Denmark under the leadership of Bishop Gruntwig had a significant impact on the development of the Swedish education system, including the pedagogical one. With his assistance in Sweden, since 1867, not only the first Higher National Schools have been opened, but also the essence of the teacher's professional activity has been rethought. The attention of educators and public figures emphasized that the learning process should be exciting, understandable and simple. The purpose of the study - "to warm the heart, to raise the mind, to properly develop the imagination, to cultivate character, thus - to promote the maturity of young people, to make them progressive citizens" [4].

The leading idea - a decisive increase in public education - that is, the establishment of public schools for the general public. The youth of the intelligent classes "moved" to the masses, 
drawing them to their cultural ideals. To become a teacher of a high school is a dream of every freethinking student [5].

Teachers of different categories received special pedagogical training in teacher's seminars (later called "colleges", then - "institutes"). In the late 1990s, there were 12 teacher training seminars in Sweden: 7 males and 5 females.

The activities were based on the following provisions:

- the whole course was free of charge;

- full training course lasted 4 years;

- boys and girls from the age of 16 who passed the examination at the national school course were admitted to the educational institution.

The seminary graduates were competitively selected in order to obtain a teaching position based on the interview. Teachers were appointed by the Parish Councils. Prior to this, the applicants were interviewed by the school board, which, following the interview, proposed to the Council the top three candidates of choice [6].

The historical experience of organizing teacher education in Sweden has laid the foundations for the further development of teacher training. According to archival data, in 1905 the number of teacher training institutions was 14 (total population was 5.4 million), and in 2005 - 25 higher education institutions for teacher training (total population - 8.6 million persons) [6].

Based on the research, it can be noted that in the process of becoming a teacher education in Sweden, the following main trends are observed: orientation towards the needs of the school and society; improving the system of organizing teacher education by developing and introducing new options for teacher training; increasing the prestige of the teaching profession.

\section{References}

1. Rosengren, Karl Erik and Ohngren, Bo. 1997. An Evaluation of Swedish Research in Education. Stockholm: HSFR.

2. Veybul', Y. 1998. Korotka istoriya Shvetsiyi [A brief history of Sweden]. Stockholm.

3. Landquist, J. 1963. Pedagogikens historia. Gleerup, Lund.

4. Isling, A. 1988. Det pedagogiska arvet. (The Pedagogical Heritage: the struggle for and against a democratic school). Stockholm: Sober Forlags AB.

5. Orlovskyy, S., 1911. Ocherky Shvetsyy [Essays in Sweden]. Higher public school in Sweden, 1.

6. Sorensen, A. 1928. Kristendomsundervisningen enligt 1919 ars undervisningsplan (Teaching religion according to the curriculum of 1919). Arbetssattet I Folkskolan VI, pp. 23-45.

УДК.373.5.016:82

DOI:10.31339/2617-0833-2020-1(28)-117-121

\section{МЕТОД СПОСТЕРЕЖЕННЯ НАД МОВНИМИ ЯВИЩАМИ ЯК ОДНИН 3 ДІЕВИХ МЕТОДІВ ВИВЧЕННЯ ФОНЕТИКИ}

Навроцька Р. Я.

\section{METHOD OF OBSERVATION OVER LINGUISTIC PHENOMENA AS ONE OF THE EFFECTIVE METHODS OF STUDYING PHONETICS}

Navrotska Ruslana

У статті розглянуто метод спостереження над мовними явищами, його основні характеристики, форми застосування. 3'ясовано, як можна застосовувати даний метод на уроках вивчення фонетики. Окреслено основні принципи використання методу, чи допомагає осмислити мовні факти та явища, чи передбачає наявність спеціально дібраного матеріалу. 